\title{
Pseudo-ancestors in the Genealogical Projects of the Emperor Maximilian I*
}

\author{
JUDITH POPOVICH AIKIN
}

Maximilian I, Holy Roman Emperor from 1493 to his death in 1519was he "the last knight" ("der letzte Ritter") or was he the first Renaissance politician north of the Alps? This question has repeatedly intrigued historians. ${ }^{1}$ The motivations for many of the emperor's most ambitious projects continue to be the subject of vigorous debate. The woodcut equestrian portrait of "Kaiser Max" by Hans Burgkmair ${ }^{2}$ evokes both the medieval chivalric code Maximilian so much admired, and the grandiose monuments of such Italian condotierri as Colleoni and Gattamelata. ${ }^{3}$ Maximilian's other artistic commissions and own creative efforts tend to alternate between these poles. His masked autobiography, Teuerdank, for example, revives medieval romances and germanic sagas. But his commission of a series of woodcuts for a "triumphal arch" and "triumphal procession" follows his Italian Renaissance counterparts in reviving Roman antiquity. His mammoth project of bronze statues, busts, and statuettes of ancestors for his own tomb has no medieval counterpart. It can best be compared with the original plans for the tomb of Pope Julius II, Maximilian's arch-rival, with which it was probably intended to vie. ${ }^{4}$

Maximilian has often been accused of lacking the force of character to carry out his thousands of ambitious schemes, which ranged from writing autobiographical novels many times the length of Teuerdank to recovering Constantinople from the Turks and getting himself elected Pope. ${ }^{5}$ But even though his proposed projects far outnumber and outweigh his successes, the plans he did carry out included many major artistic, political, diplomatic, and military victories. These successes include the acquisition for the House of Habsburg of Spain, Burgundy, and Hungary through clever marriages of himself, his children, and his grandchildren; the establishment of the Vienna Boys' Choir; and military successes in Burgundy and Northern Italy. The power of his personal charm to influence those around him was augmented by his insight into *This study, in slightly different form, was presented as a paper at the Central Renaissance Conference on March 27, 1976. 
the value of grass-roots popularity and the means to acquire it-publicity. His commissions to humanists and artists for chronicles, autobiographies, panegyrical poetry and ballads, portraits, honorific woodcuts, and - above all - his tomb in Innsbrück, are not to be attributed to conceit or to an egotistical desire for self-aggrandizement. Instead, they indicateMaximilian's canny understanding of the most effective modes of polemic available to him-the printing press and the visual arts.

Through most of Maximilian's commissions to humanists and artists there runs a single thread: each project expresses Maximilian's glory through depiction of an illustrious train of ancestors and relatives. The emperor commissioned Dr. Jacob Mennel and others to collect information on his ancestry, and to create chronicles and genealogy charts preserving this information for posterity. ${ }^{6}$ The result was dozens of genealogy charts, some huge in scale painted on parchment, canvas, or even plaster (of which twenty are still extant), ${ }^{7}$ and approximately ten chronicles and genealogical chronicles of Maximilian's ancestry. ${ }^{8}$ The ardour of some of these scholars, such as Johannes Stabius, Maximilian's chief iconographer, led them back as far as Noah. But the theological faculty at the University of Vienna, called in by Maximilian to judge the propriety of this genealogy, although accepting the myth of the Trojan genesis of the Franks and of Maximilian's house, refuted the concept ${ }^{-}$of tracing ancestry back to Biblical origins. ${ }^{9}$ Maximilian seems to state his opinion on the subject in his masked autobiography in prose, Weisskunig: the young white king (representing Maximilian) asked in vain in his youth about his ancestry. When he came to adulthood he decided to remedy the situation by sending out educated men to seek genealogical and historical records in monasteries and books, and from knowledgeable people. This research resulted in the reconstruction of his ancestry from his father back in direct lineage to Noah, and he had the collected material written up for posterity so that it would never again be lost (my paraphrase)..$^{10}$

In addition to the chronicles and genealogical charts, commissions to visual artists also depicted the newly uncovered family tree. About 1512 Maximilian charged Albrecht Dürer and other woodcut artists to create a set of monumental woodcuts depicting his glory in a triumphal procession weaving its way to a triumphal arch. ${ }^{11}$ This artistic commission depicts Maximilian's ancestors and in-laws in two series: the set of sixteen funerary statues of ancestors riding in the procession, and the relatives by blood and marriage set into the arch itself. In the centre of the arch appears Maximilian's family tree, which traces his lineage to Hector of Troy.

The other major work of art commissioned by Maximilian was his tomb in Innsbrück, planned in 1502-1508. ${ }^{12}$ The original plan involved forty over-life-size bronze sculptures of ancestors and in-laws, thirtytwo busts of Roman emperors, and one hundred statuettes of saints 
related to the Habsburg house. Although this plan was never completely instituted, twenty-eight of the large bronzes now stand in the Hofkirche in Innsbrück, along with a small selection of busts and statuettes of saints. Included here among Maximilian's relatives are his parents, the emperor Frederick III and Eleonora of Portugal; the first Habsburg emperor, Rudolf I; Maximilian's two wives, Mary of Burgundy and Blanca Maria Sforza of Milan; various of his first wife's Burgundian ancestors, including Charles the Bold and Philipp the Good;Maximilian's daughter-inlaw Joanna the Mad, heiress of Spain; his sister, Kunigunde; his children, Philipp the Handsome and Margaret of Austria.

As Anna Coreth has pointed out, the purpose of such extended genealogies was to show that Maximilian was related by blood or marriage to nearly every ruling house in Europe. ${ }^{13}$ Such a claim would aid the Holy Roman Emperor in his attempts to solidify his power base in Europe and to unify all the Christian princes under his leadership. It would help him seek allies in his military struggles and provide him with ready-made relationships for his diplomatic ventures.

But certain aspects of Maximilian's genealogy as expressed in his tomb and other ventures do not establish such obvious connections with modern political realities. Among Maximilian's blood relatives and in-laws stand such pseudo-ancestors as Julius Caesar and Charlemagne (both planned for the tomb, but not carried out), Godfrey of Bouillon, Theoderich, and King Arthur. Previously, these figures have usually been viewed as a star-studded cast designed to add lustre to a dull and often ineffective set of ancestors. But these personages, like the Trojan genesis of the House of Habsburg, may have had specific purposes in Maximilian's German and pan-European polemical schemes.

Several scholars have already defined the polemical purpose of the Trojan genesis as Maximilian's claims to the Roman Empire. ${ }^{14}$ The advantage of this lineage over, for example, lineage extending to Caesar Augustus, is that it makes a claim both to the Western Roman Empire based in Rome (Hector was related to Rome's founder, Aeneas, but superior to him in rank) and to the Eastern Roman Empire in Constantinople (Troy was thought to have originally stood on the site). Maximilian had been connected to polemic to recapture Constantinople from the Turks and to reestablish the Eastern Roman Empire since before his conception. His mother, Eleonora of Portugal, had her name changed to Helen so that, in emulation of Constantine's mother St. Helen, she could be the mother of a "second Constantine" and founder of Constantinople. At Maximilian's christening this theme reappeared: his godfather, a Byzantine prince in exile, named him for Saint Maximilian, a renowned fighter against Turkish tyranny. ${ }^{15}$ The Trojan genesis of Maximilian's family, since it provides a claim to the Eastern Roman Empire, fits into this polemical scheme. 
The other pseudo-ancestors can be similarly analysed. Julius Caesar usually appeared from the Middle Ages into the sixteenth century in chronicles or polemic claiming Trojan descent for the Franks. There he is depicted as dependent on these Frankish "relatives" for his victories in Gaul. ${ }^{16}$ Politically, he can stand for Maximilian's own campaigns against the latter-day residents of Gaul, the French. The placement of Charlemagne in the Habsburg family tree further expresses Maximilian's conflict with French imperial claims, and in addition represents an ideal of a panEuropean, Christian Roman Empire which Maximilian dreamed of someday equalling.

Godfrey of Bouillon likewise represents both an actual territorial claim and a polemical ideal. According to medieval accounts, Godfrey led the only successful crusade to Jerusalem, which he conquered from the Saracens and then ruled as king. This title-King of Jerusalem-did appear in the long list of titles passed down from imperial father to son, although political realities rendered it a hollow formula. As arch-crusader, Godfrey also represented Maximilian's dream and life-long goal of leading Europe's Christian princes on a new crusade against the present Muslim conquerors of Jerusalem, the Turks. Various literary and historical treatments of Godfrey's deeds, culminating in the late sixteenth century in Tasso's Gerusalemme Liberata, centre on Godfrey's troubles as leader of the crusade. The princes under his command are continually in conflict with each other and with him. As in these accounts, Maximilian's interest in Godfrey probably stresses the need for all Christian princes to stop their incessant bickerings and wars, and to unite (under the emperor's leadership, of course) for a concentrated campaign against the Turks. The appearance of Godfrey in Maximilian's ancestry seems to be a call-to-arms for a new crusade.

The presence of Theoderich, King of the Ostrogoths, in the Habsburg family tree is more difficult to explain, unless one is acquainted with the medieval literary tradition concerning him. In germanic saga, as preserved in the high Middle Ages in the several narratives about "Dietrich von Bern" (Theoderich of Verona), Theoderich was not merely king of the Ostrogoths (a germanic tribe controlling northern and central Italy). ${ }^{17} \mathrm{He}$ was "kunig über Roemisch rich" - king of the Roman Empire. Treacherously driven out of his rightful patrimony while still a child, Theoderich fled with his band of faithful warriors to the court of Attila the Hun near Vienna, where he was granted sanctuary. In exile there he plotted the return to his Italian domain for thirty years before finally riding south to claim his patrimony. Two of the "Dietrich" -sagas were preserved by Maximilian himself in his Heldenbuch-a collection of medieval romances and germanic sagas made under his direction about $1510-1515 .{ }^{18}$ This view of Theoderich found in the saga material provides the necessary basis for an interpretation of his place in Maximilian's ancestry. Theoderich represents both a German 


\section{2 / Renaissance and Reformation}

claim to the Roman Empire prior to Charlemagne, and an imperial claim to Italy. The story of Theoderich can also be seen as analogous to Maximilian's own situation: the Holy Roman Emperors find themselves in a sort of "exile" north of the Alps, deprived of their rightful "patrimony" in Italy, and await the opportunity to return to claim it and to be crowned once again in Rome. Maximilian's own military campaigns in Northern Italy in 1508-9 and 1516, his coronation in Trent in 1508, and his marriage to a north Italian princess in 1494 can be seen as his attempts to emulate Theoderich and claim this long-lost Italian "inheritance."

Thus far in this discussion, all of Maximilian's pseudo-ancestors have at least had some historical basis. But how did King Arthur of Round Table fame manage to climb into the Habsburg family tree? Although several English towns have claimed to have found Arthur's bones, the historical existence of this legendary king of medieval romance has not been proved. Nor can one point to a specific territorial claim King Arthur could represent for Maximilian, as with the other pseudo-ancestors. In explaining Arthur's presence, scholars have merely referred to Maximilian's love of chivalric romance. But a polemical reason for Arthur's presence can be postulated. Arthur is depicted in romance as the head of the Round Table, a group of knights dedicated to honour and service. Among these knights were included dukes, princes, and even kings. German Arthurian romances, which draw on Breton and French sources, describe the heroics of such round-table kings as Erec and Parzival; other round-table knights, like Iwein and Gawan, win kingdoms by their deeds. Couldn't Maximilian be expressing in Arthur his own desire to unite Europe's rulers-German electors, princes of Italy and northern Europe, the kings of Portugal, Spain, and France-under his own leadership? Maximilian's patronage of several chivalric orders, the Order of St. George founded by his father and the Order of the Golden Fleece inherited from his Burgundian wife, may reflect this desire to emulate the idea of a "round table" of rulers. The Holy Roman Empire, although politically ineffective, had long espoused the ideal of a Christian Europe united behind the emperor for the struggle against the infidel and heathen. King Arthur could represent the idea of an imperial moral leadership and the ideal of European unity, rather than a specific claim to territory or political power.

Thus we can say that Maximilian's genealogical concerns, whether they involve blood relatives, in-laws, or pseudo-ancestors, are intended to carry his political polemic and ideology to a pan-European audience, as well as to his own subjects and imperial princes. Three main themes have been identified in this polemic: European unity under Maximilian's leadership, various specific territorial claims for the Holy Roman Empire and the house of Habsburg, and the call to a new crusade against the Turks in Constantinople and Jerusalem. 
This polemic, as has been shown, uses historical and quasi-historical events to represent or allude to present political situations. Such historical analogy, perhaps an extension of the didactic use of historical exempla, was a persistent tool of polemical history-writing and propaganda in the sixteenth and seventeenth centuries. Perhaps the best example is the analogy made in a triumphal procession and book celebrating the victory of Maximilian's grandson Charles V over Tunis. Charles' victory is related to those of the two Scipios over Carthage (said to be on the same site); like them, Charles merits the appellation "Africanus."19 Thus events from ancient Roman history are used as a sort of "prefiguration" for contemporary deeds of a Holy Roman Emperor.

The polemical concerns discussed here do not require historical or genealogical accuracy; indeed, they seem to elicit what modern historians would consider a mingling of fiction, legend, and fact. But what was the prevailing approach to historical materials during the reign of Maximilian? The inventories of the emperor's personal library provide a clue. ${ }^{20}$ In the subdivision "Historien" (histories) the expected materials are included: chronicles, biographies of illustrious political figures (emperors, popes, kings), and the lives of Christ, the Virgin, and many saints. But in addition there are many legendary and literary materials: several verse narratives about Godfrey of Bouillon, the sagas of Dietrich von Bern, Wolfram von Eschenbach's Willehalm and Titurel, romances of Tristan and of Parzival's father Gahmuret, and one of the Charlemagne sagas. Maximilian's Heldenbuch collects a similarly mixed array of legendary, historical, and fictional narratives, from the Dietrich-sagas and Kudrun to the Arthurian romance Erec by Hartmann von Aue. Distinctions between historical fact, legendary enhancement of fact, and literary fiction were apparently not sharply drawn.

A similar relationship between fact and fiction is to be found in Maximilian's two veiled autobiographies, Teuerdank and Der Weisskunig. ${ }^{21}$ In these works, based in large part on Maximilian's own dictation, real events and personages appear in chivalric disguise. Maximilian, regarded as a slow learner by his tutors, depicts himself in these works as an exceptionally quick and able student. Although in life he was at times unhorsed in jousting, he is always victorious in these chivalric romances. The marriage which his father arranged for him with Mary of Burgundy he portrays as courtly love; his political adversaries become starkly evil and treacherous enemies of the trusting, virtuous hero.

While the clear prose of Der Weisskunig derives from German efforts in the imperial chancellery to emulate the New Style upon which Italian Renaissance literature was founded, the versified Teuerdank is decidedly an example of archaising. Its redundant style, filled with hyperboles which seem endless when describing the perfections of the characters, 
has its counterpart and obvious source in one of the sagas of TheoderichDietrichs Flucht (Theoderich's Flight). This saga is preserved in Maximilian's own Heldenbuch collection, and was undoubtedly the Theoderich saga listed in his inventories.

Not only does Maximilian alter the facts of his own life to fit the literary style of the romance genre into which he chooses to set them; the events themselves may have been coloured by his ideals as formed by literature and previous polemic. Certainly his colourful and romantic desires to participate in tournaments, to hunt with falcons, and to lead his own armies derive from his emulation of the heroes of chivalric romance and heroic saga.

One question remains: to what extent is this modelling of his genealogy, his autobiography, even his actual deeds on medieval literary tradition due to a total acceptance of its reality and validity, and to what extent is it due to an extremely perceptive insight into the popularity to be gained by publicity? Maximilian created for himself a legendary character which remains alive into the present in Germany and Austria, but he also provided the political power base from which his grandson Charles $\mathrm{V}$ and his descendants established an empire upon which, speaking literally, the sun never set.

\section{University of Iowa}

\section{Notes}

1 Adam Wandruszka, The House of Habsburg: Six Hundred Years of a European Dynasty, trans. C. and H. Epstein (Garden City, 1964), pp. 83-86.

2 Illustrated in Tilman Falk, Hans Burgkmair: Studien zu Leben und Werk des Augsburger Malers (München, 1968), fig. 43.

3 Illustrations of the Colleoni and Gattamelata equestrian monuments in Venice and Padua can be found in H. W. Janson, History of Art: A Survey of the Major Visual Arts from the Dawn of History to the Present Day (New York, 1969), figs. 482 and 515.

4 On the tomb of Pope Julius II see Charles de Tolnay, The Tomb of Julius II (Princeton, 1970).

5 On Maximilian and his various grandiose plans, see the bibliography in Dorothy Gies McGuigan, The Habsburgs (Garden City, 1966). Additional works of interest are Helga Ungar, "Nachivort," Kaiser Maximilian I: Teuerdank (München, 1968), pp. 315-42; Aloys Schulte, Kaiser Maximilian I als Kandidat für den päpstlichen Stuhl 1511 (Leipzig, 1906); Hermann Wiesflecker, Kaiser Maximilian I: Das Reich, Osterreich und Europa an der Wende zur Neuzeit (München, 1971).

6 Anna Coreth, "Dynastisch-politische Ideen Kaiser Maximilians 1," Mitteilungen des österreichischen Staatsarchivs, Festschrift für Leo Santifaller, vol. 3 (Vienna, 1950), pp. 81-105; Simon Laschitzer, "Die Genealogie des Kaisers Maximilian I," Jahrbuch der kunsthistorischen Sammlungen des Allerhöchsten Kaiserhauses, VII (1888), 1-200. On Jacob Mennel see Alphons Lhotsky, "Dr. Jacob Mennel, ein Vorarlberger im Kreise Kaiser Maximilians I," Alemannia, N.F. 2 (1936), $5 \mathrm{ff}$.

7 Laschitzer, pp. 31-39. 
8 These include the following works by Jacob Mennel: Seel unnd heiligen buch, Keiser Max. altfordern; Ain hüpsche Chronik von heidnischen und christenkunige der Teütschen und Welscher Francken; Kayserart (historical table); Kayserall und Babstall (historical tables); Kayser Maximilians besonder buch, genannt der Zaiger; Fürstliche Chronik, genannt Kaiser Maximilians Geburtsspiegel. Several other genealogical works were planned by Maximilian, as shown by Laschitzer, pp. 2 and 3: Die Stam-Chronick; der Fürsten-Spiegel; and Bildersaal deutscher Ahnen.

9 Glenn Elwood Waas, The Legendary Character of Kaiser Maximilian (New York, 1941), p. 118.

10 Kaiser Maximilians I. Weisskunig (Stuttgart, 1956), p. 225.

11 On the triumphal procession and arch, see the following works: Maximilian I. 1459-1519: Ausstellung (catalogue), Biblos-Schriften, no. 23 (Vienna, 1959), pp. 69-115; Triumph of the Emperor Maximilian I, ed. Alfred Aspland, the Holbein Society's Facsimile Reprints (London, 1875). Illustrations of these works are to be found in The Triumph of Maximilian I: 137 Woodcuts by Hans Burgkmair and Others, ed. Stanley Appelbaum (New York: Dover, 1964); and Maximilian's Triumphal Arch: Woodcuts by Albrecht Dürer and Others (New York: Dover, 1972).

12 For scholarly treatment and illustrations of the tomb, see the following works: David Ritter von Schönherr, "Geschichte des Grabmals Kaisers Maximilian I und der Hofkirche zu Innsbrück," Jahrbuch der kunsthistorischen Sammlungen des Allerhöchsten Kaiserhauses, X1 (1890), 140-268; Josef Karl Mayr, "Das Grab Kaiser Maximilians I," Mitteilungen der Österreichischen Staatsarchivs, 3 (1950), 467-92; Vinzenz Oberhammer, Die Bronzstatuen am Grabmal Maximilians I (Innsbrück, 1939); Karl Oettinger, Die Bildhauer Maximilians am Innsbrücker Kaisergrabmal, Erlanger Beiträge zur Sprach-und Kunstwissenschaft, no. 23 (Nürnberg, 1966).

13 Coreth, p. 90. William C. McDonald and Ulrich Goebel, German Medieval Literary Patronage from Charlemagne to Maximilian I: A Critical Commentary with Special Emphasis on Imperial Promotion of Literature, Amsterdamer Publikationen zu Sprache und Literatur (Amsterdam, 1973), pp. 188-89, discuss Maximilian's literary and historical patronage as an instrument of policy, and refer to his patronage as "publicistic" in intent.

14 Wandruszka, p. 86; Coreth, pp. 81-84.

15 Wandruszka, pp. 78-79.

16 E.g., Die Schriften des Alexander von Roes, ed. and trans. Herbert Grundmann and Hermann Heimpel, Deutsches Mittelalter, Kritische Studientexte der Monumenta Germaniae Historica, no. 4 (Weimar, 1949), p. 39; Matthias Flacius Illyricus, Von Ankunfft des Romischen Keysertumbs an die Deutschen, trans. W. Waldner (Ursel, 1567), fol. d3. The latter work was dedicated to Maximilian in its original Latin form, presumably between 1517 and 1519.

17 Those to which Maximilian had access are contained in Deutsches Heldenbuch, Zweiter Teil: Alpharts Tod, Dietrichs Flucht, Rabenschlacht, ed. Ernst Martin (Zürich, 19672).

18 Theodor Gottlieb, Büchersammlung Kaiser Maximilians (Amsterdam, 1968), p. 137.

19 The panegyrical book is Pompeo Bilintano, Carlo Cesare V Affricano (Naples, 1536). Two medals in the Kunsthistorisches Museum, Vienna, likewise bear this title. On the triumphal procession, see Vincenzo Forcella, Tornei e Giostre, Ingressi Trionfali e Feste Carnevalesche in Roma sotto Paulo III (Rome, 1885), pp. $37 \mathrm{ff}$.

20 Gottlieb, Büchersammlung, pp. 90 ff.

21 Kaiser Maximilian 1, Teuerdank (München, 1968); Kaiser Maximilians I Weisskunig (Stuttgart, 1956). 